\title{
マグネサイトのトポタクティックな熱分解
}

\author{
呉 基 東*・森川日出貴・岩井津一・赤尾 勝** \\ $\left(\begin{array}{c}\text { 東京工業大学 工業材料研究所 } \\ * \text { 釜山大学校工科大学 材料工学科 } \\ * * \text { 鹿教湯リハビリテーションセンター }\end{array}\right)$
}

マグネサイトとその熱分解によって得られたペリクレースとの間の結晶学的方位関係を, 高温ワ イセンベルグ法及び常温プリセッション法によって決定した. ペリクレースは次の 4 種類の方位で 晶出した.

(1) $\mathrm{M}[1 \overline{2} 0] / / \mathrm{P}[\overline{1} \overline{2}], \mathrm{M}(001) / / \mathrm{P}(111)$

(2) $\mathrm{M}[1 \overline{2} 0] / / \mathrm{P}[111], \mathrm{M}(001) / / \mathrm{P}(\overline{1} \overline{1} 2)$

(3) $\mathrm{M}[1 \overline{2} 0] / / \mathrm{P}[001], \mathrm{M}(001) / / \mathrm{P}(110)$

(4) $\mathrm{M}[1 \overline{2} 0] / / \mathrm{P}[110], \mathrm{M}(001) / / \mathrm{P}(001)$

方位関係（1）のペリクレースは多く存在し，方位関係（3)，(4) のものはまれであった. 方位関係 (2)，(3) と多分 (4) のペリクレースは元のマグネサイトの $c$ 軸に平行な 3 回軸が保持されるため に,この 3 回軸で関係付けられる 3 種類の同価な個体から成り立っている.

マグネサイト仮像を保った無数のペリクレース粒子から成る熱分解生成物は，マグネサイト表面 のペリクレースのエピタキシャルな核生成, それに引き続く結晶成長, 反応境界面に適宜起こるエ ピタキシャルなペリクレース核生成とその結晶成長の繰り返しにより理解できる.

(1979 年 7 月 7 日受付)

\section{Topotactic Thermal Decomposition of Magnesite}

Ki Dong $\mathrm{OH}^{*}$, Hideki MORIKAWA, Shin-ichi IWAI and Masaru AKAO**

$\left(\begin{array}{l}\text { Research Laboratory of Engineering Materials, Tokyo Institute of Technology, Yokohama-shi 227 } \\ \text { * Material Engineering Department, Busan National University, Korea } \\ \text { ** Kakeyu Rehabilitation Center, Chiisagata-gun 386-03 }\end{array}\right)$

Crystallographic orientation relationships between the original magnesite and the developed periclase obtained by the thermal decomposition have been determined by high-temperatureWeissenberg and precession methods. The periclase crystals were formed in the following four orientations.

(1) $\mathrm{M}[1 \overline{2} 0] / / \mathrm{P}[\overline{1} 12], \mathrm{M}(001) / / \mathrm{P}(111)$

(2) $\mathrm{M}[1 \overrightarrow{2} 0] / / \mathrm{P}[111], \mathrm{M}(001) / / \mathrm{P}(\overline{1} 12)$

(3) $\mathrm{M}[1 \overline{2} 0] / / \mathrm{P}[001], \mathrm{M}(001) / / \mathrm{P}(110)$

(4) $\mathrm{M}[1 \overline{2} 0] / / \mathrm{P}[110], \mathrm{M}(001) / / \mathrm{P}(001)$

The orientation (1) was major, while the orientations (3) and (4) were minor. The periclase crystals formed with the orientations (2) and (3) presumably as well as (4) consisted of three kinds of equivalent individuals which were related by the three fold axis of the original magnesite.

One of the possible mechanism for the formation of magnesite pseudomorphs consisting of numerous orientated periclase crystals is as follows; The nuclei of periclase initially formed by epitaxial growth on the magnesite surface by means of vapour deposition or surface diffusion grow to orientated crystals. On repeating the occasional epitaxial formation of periclase nucleus at reaction boundary and its crystal growth, a magnesite crystal decomposes into an aggregate of orientated periclase crystals.

[Received July 7, 1979]

Key-words : Magnesite, Topotactic decomposition, Periclase, Epitaxial surface growth 


\section{1. 緒訔}

二, 三の研究者は単結晶 X線法によって，カルサイト 型炭酸塩とその熱分解生成物の䦔の結晶学的方位関係に ついて研究した。野田ら!はカルサイトの [001] とカル シアの [111], [110], [100] が平行であり，これらの中 で $[111]$ が平行な場合が最も多いと報告した。また元の カルサイトの [001] とカルシアの [112] が平行である 可能性についても言及した. Haul らはドロマイトを

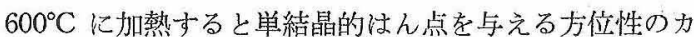
ルサイトと一様なデバイ環を与える方位性のないペリタ レースに分解し, 更に $800^{\circ} \mathrm{C}$ では方位性のあったカルサ イトも方位性のないカルシアに分解すると報告した。 Bernal ら ${ }^{3}$ は $\mathrm{FeCO}_{3}$ とその熱分解生成物の $\mathrm{FeO}$ 及び $\mathrm{Fe}_{3} \mathrm{O}_{4}$ (ともに立方晶系) との間には， $\mathrm{FeCO}_{3}$ の 3 回軸 と2 回軸が保持される方位関係があると報告した。

著者らはアルティナイト $\left[\mathrm{MgCO}_{3} \cdot \mathrm{Mg}(\mathrm{OH})_{2}\right.$ 。 $\left.3 \mathrm{H}_{2} \mathrm{O}\right]^{(1) \sim 6)}$, ネスクエオナイト $\left(\mathrm{MgCO}_{8} \cdot 3 \mathrm{H}_{2} \mathrm{O}\right)^{\text {() 9) }}$, 八 イドロマグネサイト $\left[4 \mathrm{MgCO}_{3} \cdot \mathrm{Mg}(\mathrm{OH})_{2} \cdot 4 \mathrm{H}_{2} \mathrm{O}\right]^{10) ~ 12), ~}$ マグネサイト $\left(\mathrm{MgCO}_{3}\right)^{13) \sim 15)}$ 等の一連の炭酸マグネシ ウム塩の結晶構造や加熱変化の研究を行っている際に, 水熱合成法によって大きさ $0.1 \mathrm{~mm} の$ 透明なり上ら面体 のマグネサイト単結晶 ${ }^{13)}$ を得た。この単結晶の熱分解区 応によって晶出したペリタレースを単結晶 X 線法で换 嘼 ${ }^{15}$ した結果, 晶出したペリタレースは高度の配向性を 持っていることを報告した，本研究では，マグネサイト と熱分解で生じたペリクレースとの方位関係を高温りイ

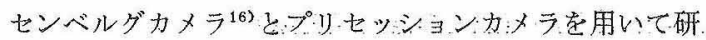
究し，その熱分解の機構を検討した

\section{2. 寒験}

大きさ $0.1 \mathrm{~mm}$ の合成マグネサイト単結晶をアルミナ セメントで石英ガラスのキャピラリーに接着し，回転軸 がマグネサイトの [120]になるように高温ワイセンベル グカメラに取り付けた。 まず常温で 0 層 [120]軸ワイセ ンベルグ写真を撮影し，次に昇温速度 $10^{\circ} \mathrm{C} / \mathrm{min}$ で加熱 し，測定点に達すると温度を一定に保ち，常温の場合と 同じ振動範同で 0 層の高温ワイセンベルグ写真を撮影し た. 测定は $\mathrm{Ni}$ フィルターで単色化した $\mathrm{CuK} \mathrm{K}_{\boldsymbol{\alpha}}$ 線を用 い, $700^{\circ} \sim 800^{\circ} \mathrm{C}$ の範囲で行った。

高次層の高温ワイセンベルグ写真は非常に広がったペ リクレースの回折はん点を与えたので方位関係を調べる には有效でなかった。したがって，ワイセンベルダ写真 の回転軸 [120]力向の情報孛得るために，高温ワイセン ベルグ写真を撮影した後にゴ二オメータヘッドをそのま まの状態でプリセッションカメラに移し，同一の試料を 用いて常温でプリセッション写真を撮影した.測定は $\mathrm{Zr}$

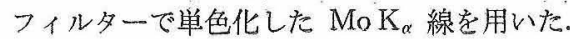

\section{3. 害 験 結 果}

\section{1 振動写真}

$800^{\circ} \mathrm{C}$ に加熱したマグネサイトの [120] 軸のX線振動 写真 ${ }^{15)}$ は, ペリクレースの 200 と 220 のデバイ環に 沿った弧状のはん点が認められた。したがって，晶出し たペリクレース結晶は高度の配向性を持っていることが 明らかである，200はん点が示す層線間隔は広がってい るはん点加ら求めた 3.6〜4.0 凡 と, 非常に広がってい るはん点から求めた $2.4 \sim 2.5 \AA$ と $5.8 \sim 8.0 \AA$ の 3 種 類である。[100]索回転軸とした場合には 200 は 0 層に 現れ，[110）と [111] を回転軸とした場合には愿線間隔 はそれぞれ $3.0 \AA$ と $3.7 \AA$ が期待され，[112] の場合 には $2.6 \AA$ と $5.2 \AA$, [113] の場合には $2.3 \AA$ と $7.0 \AA$ が期待される。したがって 3.6〜4.0 の の層線間隔は [111] 回転朝と, $2.4 \sim 2.5 \AA$ と $5.8 \sim 8.0 \AA$ の層線閒 隔は [113]回転軸と一致し，可能な回転軸としてペリク レースの [111]と [113] が考えられる. [112] 回転軸か ら期待される 200 はん点は振動写真には存在しないが, このことは [112] 回転軸の可能性を否定するものではな い.また [100]や [110] 回転軸の可能性む同様に残っ ている.

\section{2 ワインベルグ写真}

图1に $800^{\circ} \mathrm{C}$ に加熱したマグネサイトの0 層ワイセン ベルグ写真を示す．この写真の回転軸は元のマグネサイ

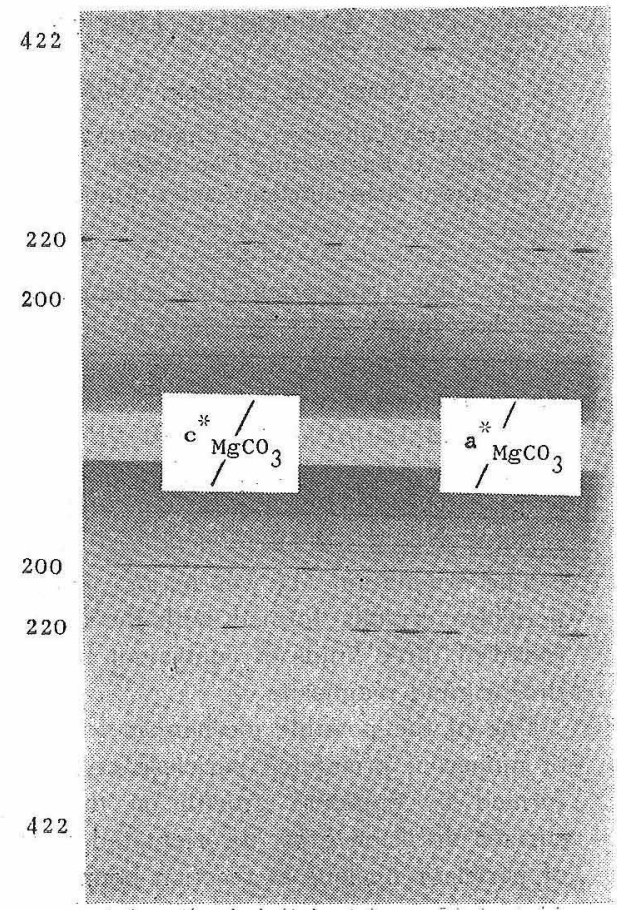

Fig. 1. 0-layer Weissenberg photograph of periclase obtained by heating magnesite at $800^{\circ} \mathrm{C}$ in situ. Oscillation about [120] of the original magnesite. 


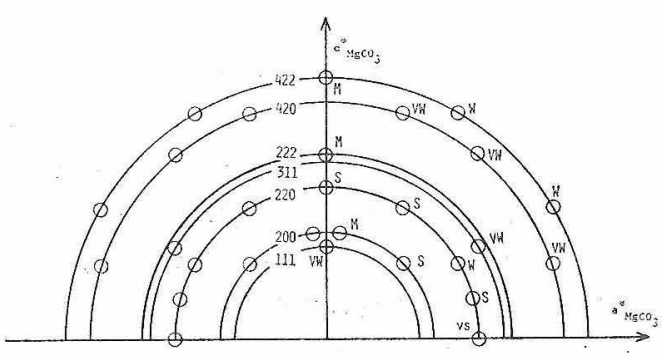

Fig. 2. Reciprocal lattice points and their intensities of the developed periclase observed on the Weissenberg photograph of Fig. 1.

トの [120] と一致し, 元のマグネサイトの $a^{*}$ 軸と $c^{*}$ 軸 は図 1 中に知印で示した。図1には，ペリクレースの $111,200,220,311,222 ４ 220,422$ のはん点が認められ た. 強度の弱い 400,331のは儿点は認められなかった。 なお，図1中の弱い粉末線はアルミナセメントによるも のである. ワイセンベルグ写真上に認められたペリクレ 一スのはん点を, 元のマグネサイトの $a^{*}$ 軸と $c^{*}$ 軸を 座標軸とする逆格子面に畫き換え, 図 2 に示した。

\section{3 プリセッション写真}

[12̄0] 軸のワイセンベルグ写真では，マグネサイト構 造中の酸素原子の最密充てん面(001) に平行な逆格子面 は観測できない。この逆格子面をみるために，同一の試 料を使って常温で 0 層プリセッション写真を撮影L，図 3 に示した. 写真には 200,220,222 のはん点が 6 回対 称の位置に認められる，これは元のマグネサイトの3回 朝が晶出したペリタレースに受けつがれることを意味し ている.

\section{4 結晶学的方位関係}

振動写真から得られた一部の共軸関係とワイセンベル グ及びプリセッション写真上の各はん点の位置と数から

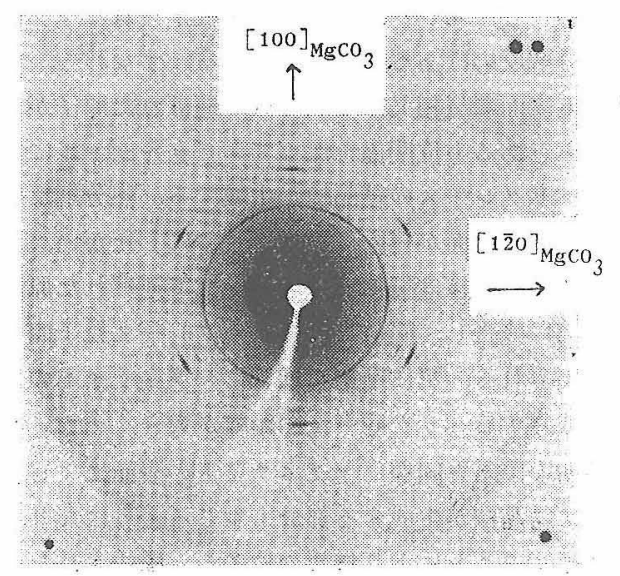

Fig. 3. 0-level precession photograph of the same periclase crystal as used for the Weis. senberg photograph of Fig. 1. Note the existence of six-fold axis along the original $c$ axis of magnesite.
次のような方位関倸を得た。

(1) $\mathrm{M}[1 \overline{2} 0] / / \mathrm{P}[\overline{1} \overline{1} 2], \mathrm{M}(001) / / \mathrm{P}(111)$

(2) $\mathrm{M}[1 \overline{2} 0] / / \mathrm{P}[111], \mathrm{M}(001) / / \mathrm{P}(\overline{1} 12)$

(3) $\mathrm{M}[1 \overline{2} 0] / / \mathrm{P}[001], \mathrm{M}(001) / / \mathrm{P}(110)$

図 4-1，2，3 にそれぞれ方位関係 (1)，(2)，(3) の指数 付けを示した。 方位関係（1）は，野田ら”がカルサイト について最も多く存在すると報告した方位関係に含ま れ，Bernal らかが $\mathrm{FeCO}_{3}$ について報告したものと同一 である. 図 3 のプリセッション写真に認められる 6 回対 称を示寸強い 220 反射はこの方位関係によるものであ る. 方位関係 (2) に基づく 222 反射も，図 3 のプリセッ ション写真上で 6 回詨称の位置に認められることから, 元のマグネサイトの 3 回軸により同洒な 3 種類の方位の

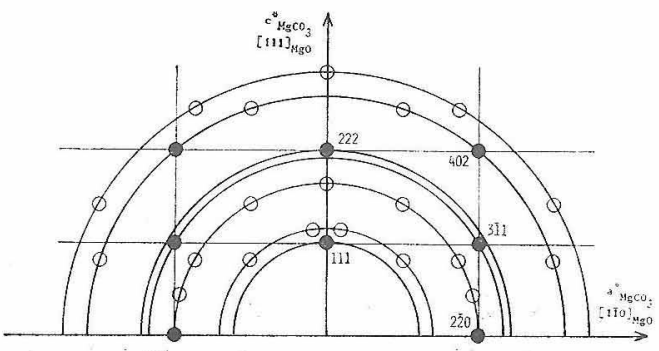

Fig. 4-1. Reciprocal lattice points of periclase due to the orientation (1):

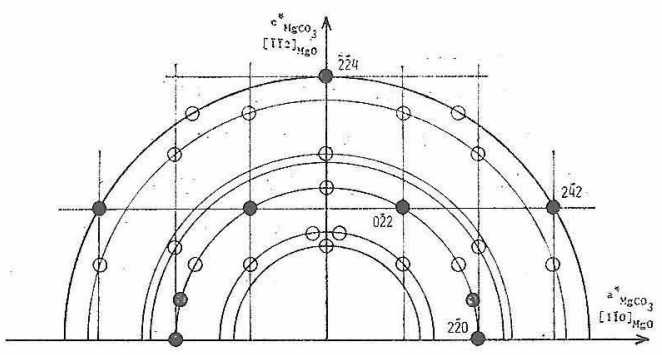

Fig. 4-2. Reciprocal lattice points of periclase due to the orientation (2). Equivalent reciprocal points produced by the persistence of three-fold axis of magnesite are marked by the shaded circles.

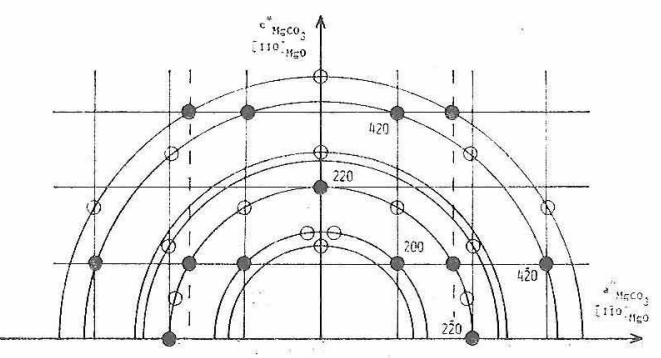

Fig. 4-3. Reciprocal lattice points of periclase due to the orientation (3). Equivalent reciprocal points produced by the persistence of three-fold axis of magnesite are marked by the shaded; circles. 
異なるペリクレース結晶（以下，擬似双晶という）が生 成したことが明らかである，言い換えればペリクレース の [112]を 3 回軸として対称操作を行った時に生じる逆 格子点も観測されるようになる.この擬似双晶によるぺ リクレースの回折はん点は図 1 のワイセンベルグ写真上 では以下の位置に認められる．すなわち [1112] に垂直 で，振動写真の回転軸 [111] と $121.5^{\circ}$ 傾いた方向に

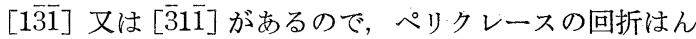
点が広がっていることを考慮に入れると，これらの軸を 回転軸としたペリクレースの0 層写真も重なってワイセ ンベルグ写真上に撮影されねばならない，擬似双晶によ

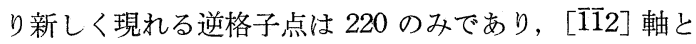
$73^{\circ}$ 傾いた方向に存在し, 図 4-2 中に陰をつけた丸印で 示した. 方位関係 (3) のペリクレースも同様にペリクレ 一スの [110] 軸を 3 回軸とする擬似双晶が存在する．プ リセッション写真上では 6 回対称の位置に 200 が認めら れることに相当する.すなおち [110]に垂直で, 振動写 真の回転軸 $[001]$ と $125.3^{\circ}$ 傾いた方向に $[1 \overline{1} \overline{1}]$ 又は [111] があるので近似的にはこれらの軸を回転軸とした ペリクレースの回折はん点, 図 4-2の黒丸の逆格子点を $90^{\circ}$ 回転した逆格子点が重なって現れる. プリセッショ ン写真上の弱い 200 の強度からこの方位関係（3）を保 って晶出するペリクレースの量は少ないことが明らかに なった。

以上の 3 組の方位関係によりワイセンベルグとプリセ ッション写真上に認められた大部分の回折はん点は説明 された. マグネサイト $c^{*}$ 軸付近に認められる極めて広 がった 200 回折はん点（図 2 では $c^{*}$ 軸から $8^{\circ}$ 離れた 2 個のはん点として図示) のみが残される. 野田ら は カルサイトの $c$ 軸とカルシアの $[100]$ が平行であると報 告しているので, この 200 は,

(4) $\mathrm{M}[1 \overline{2} 0] / / \mathrm{P}[110], \mathrm{M}(001) / / \mathrm{P}(001)$

の方位関係に属すると推察される. 200 以外の回折はん 点が認められないので，この方位関係を保って晶出する ペリクレースは極めて少ない，また方位関係 (2)，(3) に認められた擬似双晶の存在は強度が弱いために明らか でない.

以上の 4 種類の方位関係を保って晶出するペリクレ一 スの外に，元のマグネサイトと方位関係を全く保たない で晶出するペリクレースも存在することは振動写真のデ バイ環に沿った粉末線からも明らかである。

\section{4. 考察}

マグネサイトとその加熱分解生成物のペリクレースと の間には共軸関係が存在することが明らかになった。こ れらの共軸関係はダイアスポアとその加熱分解生成物の

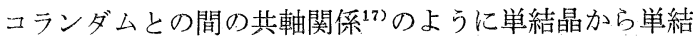
晶的双晶へ変化する互いの軸の間の不一致が極めて小さ
いものではない. 本研究で明らかになった 4 種類の方位 関係のうち，(1) は熱分解反忘中も酸素原子のパッキン グが保持される不均一反応機構 ${ }^{18)}$ で説明されるものであ る. ペリクレースの晶出には，マグネシウム原子はペリ クレースを作るように, 炭素原子は炭酸ガスを作って放 出されるように互いに拡散して原子の再配列が行われる 際に，理想的でなかった酸素原子パッキングが規則正し いものに変わると同時に $c$ 軸方向の六方密充てんが立方 密充てんに変わることが必要である．方位関係 (2) の場 合には酸素原子のパッキング面がマグネサイトとペリク レースで $19^{\circ}$ 傾斜しており, 単純に不均一反応機構で説 明されるものではない，方位関係 (3)，(4) は晶出され るペリクレースの量は少ないが, 酸素原子のパッキング だけを基本とした反応機構では理解できない.

ダイアスポアからコランダムの晶出は 1 種類の方位関 係を保って反応が起こり，放出される酸素原子の割合は ダイアスポア中の酸素原子の $1 / 4$ と低い. ダイアスポア 仮像は外見上密であり，ところどころに孔が観察され る. 一方マグネサイトからペリクレースの晶出は 4 種類 の方位関係を保って反応が起こり, 放出される酸素原子 の割合は $2 / 3$ と高い.マグネサイト仮像は無数の粒状の ペリクレースから構成されている. ペリクレースがマグ ネサイト構造中の酸素原子のパッキングを保って晶出す るならば理想的には 1 種類の方位関係しが存在せず，そ の仮像は粒状の集合体ではなく，無数の孔や割れ目のあ るスポンジ状であろう。したがってマグネサイトの熱分 解については不均一反応機構と類似した別の反応機構を 考える必要がある. 熱分解生成物が元の化合物の表面に エピタキシャルに成長する ${ }^{199}$ と言う考えがある.この場 合には陽イオンも陰イオンも元の位置から移動して別の 位置で再配列することが不均一反応機構と異なってい る.このエピタキシャル表面成長を仮定すればマグネサ イトの分解反応はある程度説明できる. 寸なわち, マグ ネサイト表面に気相又は表面拡散で運ばれた原子がマグ ネサイトとある方位関係を保ってエピタキシャルに結晶 化し，ペリクレースの結晶核が生成する. 熱分解反応が マグネサイト表面から内部に進行するにしたがい，ペリ クレースの結晶核は気相又は表面拡散で運ばれた原子に より次第に成長し，炭酸ガスはペリクレ一ス粒子間を通 って放出される．更に反応が進むとマグネサイトの表面 と結晶成長するペリクレ一スの距離が大きくなるため に，最初の段階と同様にマグネサイトの表面にエピタキ シャルに結晶核が生成する部分も生じるようになり，こ れが成長することにより無数の粒子から構成された，多 孔質の，元のマグネサイトの仮像を保った，しかも共軸 関係を保ったペリクレースの生成が可能であると思われ る.この際，酸素原子のパッキング面が $19^{\circ}$ 傾斜してい る方位関係 (2) の結晶核もマグネサイト表面の状態によ 
っては生成され，成長する. この可能性は，酸素原子の パッキングが保持される不均一反応機構の場合よりむ酸 素原子も移動するエピタキシャル表面成長機構の方がは るかに大きいと思われる。

\section{5. 総 括}

マグネサイト単結晶とその加熱分解により生じたペリ クレースとの共軸関係を高温ワイセンベルグカメラとプ リセッションカメラを用いて検討し，次の結果を得た．

（1）本文中に示した 4 種類の方位関倸が明らかにさ れた. 晶出したマグネシアの量は方位関係 (1) が最む多 く，(3)，(4) は少なかった。

（2）方位関倸 (2)，(3)，(4) のペリクレースは元の マグネサイトの $c$ 軸に平行な 3 回軸が分解反応を通して 保存されるために 3 種類の方位の異なる結晶から成り立 っている.

（3）最も多い方位関係（1)のペリクレースの晶出だ けについては酸素原子のパッキングが反応中を通して保 存される不均一反応機構で説明できる現象であるが， 4 種類もの方位関係が存在するマグネサイトの熱分解全体 を説明できない，本研究では多種類の方位関係の存在を も説明できるように不均一反応機構を変形し, エピタキ シャル表面成長による核生成を導入し, 熱分解反応の解 釈を試みた。

$$
\text { 文献 }
$$

1）野田稲吉, 桑原辰雄, 窐協, 52, 142-45 (1944).
2) R.A.W. Haul and H. Wilsdorf, Acta Cryst., 5, 25055 (1952).

3) J.D. Bernal, D.R. Dasgupta and A.L. Mackay, Clay Minerals Bull., 4, 15-30 (1959).

4) S. Iwai, H. Aoki, T. Shimamune and H. Morikawa, Am. Mineral., 55, 1055-58 (1970).

5) S. Iwai, H. Tagai and H. Aoki, Z. Anorg. Allg. Chem., 384, 191-92 (1971).

6) M. Akao and S. Iwai, Acta Cryst., B 33, 3951-53 (1977).

7）岩井津一, 室谷 宽, 森川日出貴, 青木秀希, 窯協, 77, 411-17 (1969).

8) K. Oh, M. Akao, H. Morikawa and S. Iwai, Bull. Tokyo Inst. Tech., 120, 29-34 (1974).

9) S. Iwai, Y. Sotome, H. Aoki and H. Morikawa, Am. Mineral., 56, 628-29 (1971).

10) M. Akao, F. Marumo and S. Iwai, Acta Cryst., B 30, 2670-72 (1974).

11) M. Akao and S. Iwai, Acta Cryst., B 33, 1273-75 (1977).

12) M. Akao and S. Iwai, Report of the Res. Lab. Eng. Mat., Tokyo Inst. Tech., 4, 29-41 (1979).

13) K. Oh, H. Morikawa, S. Iwai and H. Aoki, Am. Mineral., 58, 339-40 (1973).

14) K. Oh, H. Morikawa, S. Iwai and H. Aoki, Am. Mineral., 58, 1029-33 (1973).

15）呉 基東, 森川日出貴, 岩井津一, 青木秀希, 窯協, 82, 442-46 (1974).

16) S. Iwai, H. Tagai, M. Kato and T. Shimamune, Bull. Tokyo Inst. Tech., 103, 105-10 (1971).

17) S. Iwai, H. Yamamoto, H. Morikawa and M. Isobe, Mineral. J., 7, 137-58 (1973).

18) M.C. Ball and H.F.W. Taylor, Mineral. Mag., 32, 754-66 (1961).

19) H.F.W. Taylor, 私信 (1979).

論文・Paper

\section{テトラカルシウムアルミノフェライトーセッコウ系の エトリンガイト生成期における水和反応速度と鉄の挙動}

福原 実・後藤誠史・浅賀喜与志 $\cdot 大$ 門正機 近藤連一次野吉雄*

(* 東京工業大学 工学部 無機材料工学科)

\footnotetext{
テトラカルシウムアルミノフェライト, $4 \mathrm{CaO} \cdot \mathrm{Al}_{2} \mathrm{O}_{3} \cdot \mathrm{Fe}_{2} \mathrm{O}_{3}$, のセッコウ存在下でのエトリンガ イト生成期に扔ける反応機構の考察を行った.

水和生成物は， $\mathrm{Fe}$ をずが含むエトリンガイト及びゲル状の黒色の粒子であった．この黒色の 粒子は $\mathrm{Fe}$ 成分に富んで扔り, 未反応 $4 \mathrm{CaO} \cdot \mathrm{Al}_{2} \mathrm{O}_{3} \cdot \mathrm{Fe}_{2} \mathrm{O}_{3}$ と外形が非常に似ていることにより, 末反応 $4 \mathrm{CaO} \cdot \mathrm{Al}_{2} \mathrm{O}_{3} \cdot \mathrm{Fe}_{2} \mathrm{O}_{3}$ より $\mathrm{Ca}$ 成分及び, $\mathrm{Al}$ 成分が溶出して生成したものと考えられる.

反応機構の解析はコンダクションカロリメーターを用いた 熱測定の結果より行った. その結果 $4 \mathrm{CaO} \cdot \mathrm{Al}_{2} \mathrm{O}_{3} \cdot \mathrm{Fe}_{2} \mathrm{O}_{3}$ の元の場所に生成している 水和反応物層中の 拡散がエトリンガイト生成反応 の律速段階であることが判明した.

(1979 年 10 月 4 日受付)
} 